\title{
PENGARUH EXERCISE INTENSITAS TINGGI TERHADAP KETEBALAN ENDOMETRIUM MENCIT (MUS MUSCULUS)
}

\section{THE EFFECT HIGH INTENSITY EXERCISE TO THICKNESS OF ENDOMETRIUM MICE (MUS MUSCULUS)}

\author{
Aizah Ari Setyana Yuli ${ }^{1}$, Gadis Meinar Sari ${ }^{2}$, Ashon Sa'adi ${ }^{2}$ \\ 1. Program Studi Pendidikan Bidan, Fakultas Kedokteran, Universitas \\ Airlangga \\ 2. Fakultas Kedokteran, Universitas Airlangga \\ Alamat korespondensi: \\ J1. Luntas, Tambaksari, Surabaya \\ Email: aeezahaeri@gmail.com
}

\begin{abstract}
Abstrak
Latar Belakang : Exercise dapat menyebabkan terbentuknya reactive oxygen species (ROS). Ketidakseimbangan antara antioksidan endogen dan ROS dapat menyebabkan stres oksidatif. Stres oksidatif dapat menyebabkan infertilitas pada wanita melalui berbagai mekanisme. Endometrium yang tidak sempurna karena ROS tidak dapat mendukung embrio dan perkembangannya. Penelitian ini bertujuan untuk menganalisa perbedaan ketebalan endometrium pada mencit yang exercise intensitas tinggi. Metode : Penelitian ini true experimental dengan rancangan randomized posttest only design. Besar sampel adalah 7 ekor tiap kelompok, yang terdiri dari 2 kelompok. Kelompok kontrol dan kelompok exercise intensitas tinggi. Data yang didapatkan adalah ketebalan endometrium mencit. Hasil : hasil uji mann-whitney menunjukkan hasil yang signifikan dengan $\mathrm{P}=0,006$. Kesimpulan : exercise intensitas tinggi dapat mempengaruhi ketebalan endometrium..
\end{abstract}

Kata kunci : exercise intensitas tinggi, ketebalan endometrium, , mencit ( Mus musculus)

\section{Abstract}

Background: Reactive Oxygen Species (ROS) is formed by exercise. Oxidative stress is caused by an imbalance between endogenous antioxidants and ROS. Oxidative stress causes infertility in women through mechanisms. Because of ROS, endometrium can not support the embryo and its development. This research aim to analyze different of endometrial thickness mice with high intensity exercise. Methods: This research is true experimental researh with randomized posttest only design. The sample size is 7 female mice each group, devided into 2 groups. The control group, and the high-intensity exercise group. Data obtained from mice endometrial thickness Results: mann-whitney gave significant result at level $p=0.006$. Conclusion: high intensity exercise can effect the thickness of the endometrium.

Keywords: high intensity exercise, thickness of endometrium, , mice (Mus musculus)

\section{PENDAHULUAN}

Exercise didefinisikan sebagai rangkaian gerakan yang dapat melatih fisik dan psikis untuk meningkatkan kesehatan. Exercise dapat memberikan efek positif terhadap tubuh dan mencegah berbagai penyakit. Di samping manfaat tersebut ada beberapa risiko terkait dengan intensitas exercise, terutama untuk atlet wanita. 
Risiko ini sering dikenal dengan female athlete trial yang terdiri dari amenore, osteoporosis dan gangguan makan (Holsgaard dan Roos, 2012). Ada bukti yang menunjukkan bahwa dengan intensitas yang tinggi dapat menyebabkan disfungsi menstruasi dan subfertilitas seperti pada atlet wanita berperforma tinggi. Pada penelitian sebelumnya menunjukkan intensitas tinggi berkaitan dengan amenorea, oligomenore, defisiensi fase luteal, dan anovulasi serta gangguan aksis hipotalamus-pituitari-adrenal (Ahrens et al., 2014).

Pulsasi dari pelepasan GnRH penting sebagai fungsi dari sistem reproduksi, nutrisi yang tidak adekuat dan stres dapat merusak pelepasan hormon gonadotropin. Pada atlet wanita terjadi penurunan GnRH yang mempengaruhi produksi LH dan FSH yang menyebabkan stimulasi ovarium terganggu dan menghentikan produksi estradiol (Holsgaard dan Roos, 2012). Dengan kadar hormon estrogen yang rendah akan mempengaruhi proliferasi endometrium. Endometrium mengeluarkan banyak zat dan mendukung lingkungan yang bergizi untuk embrio awal. Selain itu endometrium berperan penting dalam menekan respon imun saat terjadi kehamilan yang dipengaruhi oleh hormon (Speroff dan Fritz, 2011).

Exercise dapat meningkatkan kontraksi otot yang bersifat akut dan berat serta tidak terkontrol. Kontraksi otot akut karena beban berat dapat menimbulkan iskemia-reperfusi pada area otot yang aktif, yang pada keadaan ini dapat menyebabkan penurunan aliran darah dan oksigen sementara sehingga timbul keadaan iskemi. Saat otot berelaksasi, terjadi reperfusi yang memerlukan oksigen dalam jumlah yang banyak, dan keadaan ini dapat menyebabkan terbentuknya reactive oxygen species (ROS). Saat produksi ROS meningkat, terjadi adaptasi fisiologis untuk menghadapinya yaitu dengan membentuk antioksidan endogen. Akan tetapi, apabila ROS terbentuk sangat banyak menyebabkan ketidakseimbangan antara antioksidan endogen dan ROS yang disebut keadaan stres oksidatif (Sylviana et al., 2017).

ROS memiliki peran dalam menjaga jaringan, pensinyalan hormon, pematangan oosit, folikulogenesis, fungsi tuba, streroidogenesis ovarium, siklus perubahan endometrium dan fungsi germinal. ROS yang meningkat akibat stres lingkungan menyebabkan kerusakan struktur sel (Gupta et al., 2008). Stres oksidatif dapat menyebabkan infertilitas pada wanita melalui berbagai mekanisme. 
Folikel ovarium mengalami kerusakan langsung pada oosit akibat dari stres oksidatif. Ketika pembuahan menyebabkan apoptosis untuk fragmentasi embrio kegagalan implantasi, aborsi, atau kelainan kongenital pada keturunan. Stres oksidatif pada tuba fallopi dapat menyebabkan efek pada embrio. Endometrium yang tidak sempurna karena ROS tidak dapat mendukung embrio dan perkembangannya (Gupta et al., 2008).

Penelitian ini bertujuan untuk menanalisa pengaruh exercise intensitas tinggi terhadap ketebalan endometrium pada mencit.

\section{METODE}

Tempat penelitian ini dilakukan di Laboratorium Embriologi Fakultas Kedokteran Hewan Universitas Airlangga

Desain penelitian penelitian true experimental menggunakan rancangan randomized posttest only control group design. Terdiri dari 2 kelompok yaitu kelompok kontrol dan kelompok perlakuan exercise intensitas tinggi.

Teknik sampling yang digunakan adalah simple random sampling. Populasi pada penelitian ini adalah hewan coba mencit betina (mus musculus). Kriteria inklusi, yaitu: mencit betina (Mus musculus), usia 3-4 bulan dengan berat 18-35 gram. Kriteria eksklusi, yaitu: mencit sakit selama masa adaptasi 7 hari (gerak tidak aktif) sebelum exercise intensitas tinggi. Di keluarkan Mencit mati selama perlakukan berlangsung. Jumlah replika sampel setiap kelompok adalah 7 ekor.

Pengumpulan data Mencit dibagi menjadi 2 kelompok. Sebelum perlakuan dilakukan pemeriksaan swab vagina untuk mengetahui fase estrus mencit. Pemeriksaan hapus vagina untuk mengetahui siklus estrus. Perlakuan merenangkan tikus dengan pembebanan $18 \%$ berat badan dengan waktu $90 \%$ dari waktu maksimumnya (T90) dengan interval 2 kali, waktu istirahat diantara 2 interval adalah 2 kali T90. Direnangkan dengan frekuensi 3 kali perminggu, selama 28 hari. Setelah 28 hari dilakukan pembedahan untuk pengambilan uterus. Selanjutnya dilakukan pembuatan sedian histologi uterus pewarnaan HE.

Analisis data Data dari hasil pengukuran ketebalan endometrium mencit, dianalisis menggunakan Mann-whitney untuk mengetahui kelompok mana yang berbeda.

\section{HASIL DAN PEMBAHASAN}


Tabel 1 Berat badan mencit antar kelompok sebelum diberikan perlakuan

\begin{tabular}{lll}
\hline Karakteristik & \multicolumn{2}{c}{ Kelompok perlakuan } \\
\cline { 2 - 3 } & kontrol & exercise intensitas tingi \\
\hline BB (gram) & $31,57 \pm 2,63$ & $26,0 \pm 4,54$ \\
\hline
\end{tabular}

Pada tabel 1 diketahui rerata berat badan kelompok kontrol lebih besar dari kelompok perlakuan exercise intensitas tinggi.

Hasil analisis yang digunakan pada penelitian ini adalah Mann-whitney.

Tabel 2 Hasil uji beda Mann-whitney

\begin{tabular}{llcc}
\hline \multicolumn{1}{c}{ Kelompok } & $\mathrm{N}$ & $\begin{array}{c}\text { Rerata }(\mu \mathrm{m}) \pm \\
\text { Simpangan Baku }\end{array}$ & Nilai P \\
\hline Kontrol & 7 & $514,48 \pm 219,41$ & 0,006 \\
\hline Exercise intensitas tinggi & 7 & $195,39 \pm 161,15$ & \\
\hline
\end{tabular}

Pada kelompok perlakuan exercise intensitas tinggi memiliki rerata ketebalan endometrium 195,39 $\mu \mathrm{m}$ lebih rendah dibandingkan dari kelompok kontrol 514,48 $\mu \mathrm{m}$. Terdapat perbedaan bermakna antara kelompok kontrol dan kelompok perlakuan exercise intensitas tinggi setelah dilakukan analisis. Dari data tersebut exercise intensitas tinggi dapat menyebabkan penurunan ketebalan endometrium.

Exercise ringan maupun berat dapat menyebabkan reactive oxygen spesies (ROS) yang dapat memicu radikal bebas dalam tubuh. Pada keadaan tertentu ROS dapat melebihi sistem pertahanan yang disebut dengan stres oksidatif (Agarwal et al., 2005). Saat exercise terjadi peningkatan melondialdehide (MDA) dalam darah dan petene dalam pernapasan. Stres oksidatif dapat menyebabkan infertilitas pada wanita melalui berbagai mekanisme. Pada endometrium yang tidak sempurna karena ROS, tidak dapat mendukung embrio dan perkembangannya (Gupta et al., 2008). Endometrium merupakan lapisan epitel yang melapisi rongga rahim yang berfungsi mempersiapkan tempat implantasi dan nutrisinya, serta membentuk bagian maternal plasenta hasil konsepsi. Fluktuasi hormon pada ovarium menyebabkan perubahan struktur pada endometrium (Fawcett, 2002).

Exercise berlebihan dapat menyebabkan gangguan pada hipotalamus dalam mensekresikan GnRH yang dikenal dengan amenore hipotalamus fungsional (FHA). Amenore hipotalamus fungsional (FHA) diklasifikasikan sebagai hipogonadisme hipogonadotropik yang terjadi karena penyimpangan pelepasan pulsatil dari pelepasan gonadotropin hormon $(\mathrm{GnRH})$ dari hipotalamus. Penurunan 
sekresi gonadotropin menyebabkan berkurangnya produksi estradiol di ovarium. Poros hipotalamus-hipofisis-ovarium yang terganggu dalam kasus FHA biasanya dikaitkan dengan stres, kehilangan berat badan dan / atau latihan fisik yang berlebihan serta merupakan penyebab paling umum dari amenore sekunder. Tergantung dari faktor yang memunculkannya, FHA terdiri dari tiga kelas yaitu terkait penurunan berat badan, stres, dan olahraga (Meczekalski et al., 2014).

Pada atlet wanita terjadi penurunan GnRH yang mempengaruhi produksi LH dan FSH yang menyebabkan stimulasi ovarium terganggu dan menghentikan produksi estradiol (Holsgaard dan Roos, 2012). Estrogen menyebabkan proliferasi sel dan membentuk ulang endometrium setelah menstruasi. Estrogen merangsang lapisan epitel basal endometrium untuk membelah diri dan berproliferasi membentuk dinding mukosa tebal dengan banyak kelenjar endometrium. Estrogen berperan untuk angiogenesis (pertumbuhan pembuluh darah baru), membentuk jaringan vaskular yang ekstensif, arteri dan vena spiral di dalam endometrium. Peningkatan aktivitas mitotik dan sintesis DNA inti dan RNA sitoplasmik menunjukkan intensitas tinggi lapisan fungsionalis yang merupakan tanda dari fase proliferasi. Estrogen meningkatkan ketebalan endometrium dan selama proliferasi estrogen mempersiapkan endometrium memicu reseptor progesteron. Progesteron melanjutkan perkembangan sel-sel kelenjar yang sebelumnya dipengaruhi oleh estrogen.

\section{SIMPULAN DAN SARAN}

Terdapat perbedaan yang signifikan pada rerata ketebalan endometrium pada kelompok mencit yang diberikan exercise intensitas tinggi. Hal ini menunjukkan bahwa exercise intensitas tinggi dapat menyebabkan penurunan ketebalan endometrium pada mencit (Mus musculus).

Sebaiknya pada penelitian selanjutnya dilakukan swab akhir sebelum dilakukan pembedahan pada mencit, agar diketahui siklus estrus pada mencit dan dilakukan pemeriksaan hormon untuk mengetahui perubahan hormon yang terjadi yang dapat mempengaruhi perubahan pada endometrium mencit.

\section{DAFTAR PUSTAKA}


Agarwal, A. et al. (2005) Role of oxidative stress in female reproduction, Reproductive Biology and Endocrinology, 3(1), p. 28. Diperoleh dari: http://rbej.biomedcentral.com/articles/10.1186/1477-7827-3-28 (diakses pada 28 Oktober 2018)

Ahrens, K. A. et al. (2014) The effect of physical activity across the menstrual cycle on reproductive function, Annals of Epidemiology. Elsevier Inc, 24(2), pp. 127-134. Diperoleh dari : doi: 10.1016/j.annepidem.2013.11.002.

Fawcett, Don (2002) Buku Ajar Histologi. Jakarta : EGC, pp. 60-71

Function, S. et al. (2005) Review Oxidative stress and its implications in female infertility - a clinician's perspective, 11(5), pp. 641-650.

Gupta, S. et al. (2008) The Impact of Oxidative Stress on Female Reproduction and ART: An Evidence-Based Review, in Rizk, B. R. M. B. et al. (eds) Infertility and Assisted Reproduction. Cambridge: Cambridge University Press, pp. 629-642.Diperoleh dari: doi: 10.1017/CBO9780511547287.067.

Holsgaard, A. and Roos, E. M. (2012) Effects of physical exercise on female reproductive system, 48(4), pp. 577-585.

Meczekalski, B. et al. (2014) Functional hypothalamic amenorrhea and its influence on women's health, Journal of Endocrinological Investigation, 37(11), pp. 1049-1056. Diperoleh dari: doi: 10.1007/s40618-014-0169-3.

Speroff, L. and Fritz, M. (2011) Clinical Endocrinology and Infertility, Lippincott Williams \& Wilkins. Diperoleh dari: doi: 10.4183/aeb.2005.240.

Sylviana, N. et al. (2017) The Effect of Astaxanthin and Regular Training on Dynamic Pattern of Oxidative Stress on Male under Strenuous Exercise, IOP Conference Series: Materials Science and Engineering, 180(1), p. 012173. Diperoleh dari : doi: 10.1088/1757-899X/180/1/012173. 